Fanum

Sociológico

\section{Forum Sociológico}

Série II

$27 \mid 2015$

Mobilidade científica \& imigração qualificada

\title{
Moving to integrate international students at Oswald Cruz Foundation, Rio de Janeiro
}

Isabela Cabral Félix de Sousa

\section{(2) OpenEdition}

1 Journals

Edição electrónica

URL: https://journals.openedition.org/sociologico/1325

DOI: $10.4000 /$ sociologico. 1325

ISSN: 2182-7427

Editora

CICS.NOVA - Centro Interdisciplinar de Ciências Sociais da Universidade Nova de Lisboa

Edição impressa

Data de publição: 21 dezembro 2015

Paginação: 23-30

ISSN: 0872-8380

\section{Refêrencia eletrónica}

Isabela Cabral Félix de Sousa, «Moving to integrate international students at Oswald Cruz Foundation, Rio de Janeiro», Forum Sociológico [Online], 27 | 2015, posto online no dia 31 maio 2016, consultado o 30 março 2022. URL: http://journals.openedition.org/sociologico/1325 ; DOI: https://doi.org/10.4000/ sociologico. 1325 


\title{
MOVING TO INTEGRATE INTERNATIONAL STUDENTS AT OSWALD CRUZ FOUNDATION, RIO DE JANEIRO
}

\author{
Isabela Cabral Félix de Sousa \\ Fundação Oswaldo Cruz, Escola Politécnica de Saúde Joaquim Venâncio, Laboratório de Iniciação Científica na Educação \\ Básica
}

\begin{abstract}
Resumo
O propósito deste trabalho é o de descrever o papel desempenhado por seminários de boas vindas para estudantes estrangeiros na Fundação Oswaldo Cruz (Fiocruz) no campus do Rio de Janeiro, uma instituição governamental dedicada a trabalhar com questões de saúde. O Brasil ocupa um importante papel na economia mundial e atrai estudantes estrangeiros e migrantes. Neste novo milênio, o foco de cooperação Sul-Sul com países da América do Sul e África ganhou maior importância para o Brasil tanto nos setores educacionais como nos de saúde. O governo brasileiro começou a dar prioridade para um processo mais ativo que envolve intercâmbios com instituições, profissionais e estudantes. No campo da saúde, o Brasil vem ocupando um papel prioritário na formação de profissionais de outras nações. A pesquisa qualitativa ilustra no campus principal desta instituição uma tendência para a integração dos estudantes internacionais com os nacionais.
\end{abstract}

Palavras-chave: saúde, Brasil, integração social, mobilidade estudantil

\begin{abstract}
The purpose of this paper is to critically analyze the seminars that aim to integrate international students at Oswald Cruz Foundation (Fiocruz) Rio de Janeiro's campus. Fiocruz is a governmental research institution devoted to health issues. Brazil occupies an important role in the world economy and attracts international students and migrants. In this new millennium, the focus of South-South cooperation with countries of South America and Africa gained more importance for Brazil in both the education and health sectors. The Brazilian government begun to give priority to a more active process of exchange among institutions, professionals and students. In the health sector, Brazil has played a leading role in training professionals from other nations. The qualitative analysis illustrates that, in the main campus of this health research institution, one trend is integrating the international student body with the national one.
\end{abstract}

Keywords: health, Brazil, social integration, student mobility

\section{Introduction}

The exchange of international knowledge through universities is an old practice that dates back to the Middle Ages (Ojima; Aguirre et al. 2014). Since the last century, internationalization in higher education refers to different processes. Castro and Cabral Neto (2012) explain that the internationalization process in the higher education system has emerged due to demands outside this system in two different historical periods. In the first period, in 1945, it materialized after the Second
World War II with the attempt to rebuild the countries through technical assistance. This assistance involved cultural and scientific interchanges that encompassed student mobility and scholarships. In the second period, beginning in the end of last century until today, the process has responded to the demands of a global economy where countries, regardless of their level of development, have been eager to participate in the knowledge society and, therefore, by trying to interchange services and educational products. Morosini (2011) explains that in the knowledge society higher education institutions 
expanded. This author also contends that while the internationalization of higher education was strategic related to globalization, regionalization of societies and the influence of higher education, the new transnationalization of the educational system reflects profit-making reasons.

In Brazil as well, the internationalization process has existed for a long time in institutions dedicated to research and educational programs, but this process has intensified. Increasingly, institutions rank more positively when their professors, researcher and students engage in actions towards internationalization. This ranking affects both the prestige of people involved as well as their access to grants and fellowships. The fact that the internationalization of institutions is many times an external process has implications not only to social actors' commitment but also to how and to which extent institutions embrace this process in both formal and informal circumstances.

\section{The internationalization of Brazil and its educational institutions}

Worldwide, despite the rapid increase in the flow of international student mobility, this process is somewhat neglected in research on migration (King and Raghuram, 2013). There is a debate whether a foreign student should be defined as migrant mobility. Yet, authors such as King and Raghuram (2013) remember that the time of three or four years to acquire a college degree fits the conventional statistical of international migration. Moreover, many students become migrants.

The foreign students' mobility often depends on international cooperation. In the Brazilian case, international university cooperation in the past century focused primarily on exchanges with First World countries like Germany, United States and France, a South-North cooperation. However, some initiatives have occurred in the twentieth century, showing that Brazil also encouraged academic South-South cooperation. Since 1965, the Undergraduate Student Program Agreement (PEC-G) has funded foreign students from developing countries with which Brazil maintains educational, cultural, or scientific and technological agreement. Likewise, the Graduate Student Program Agreement (PEC-PG), established in 1981, has offered fellowships for developing countries nationals with which Brazil has national agreements, aiming to prepare students in graduate studies (master and doctorate). Therefore, since the last century many undergraduate and graduate students from Africa, Latin America, the Caribbean and Asia have received fellowships by these Brazilian programs to study at Brazilian higher education institutions.

In the twentieth century, other Brazilian initiatives with developing countries also deserve attention. Zamberlam; Corso, et al. (2009) tell us that the creation of the Brazilian Cooperation Agency had the support of the United Nations Development Programme (UNDP) and that in the 90's emerged the Community of Portuguese Language Countries (CPLP).

Since 2001, within the Brazilian university system the South-South international cooperation became preeminent. According to Krawczyk (2008: 46): "Today there is in the foreign policy of the Brazilian government a greater incentive for the South-South cooperation with India, China and Africa; also with Portuguese-speaking countries and Latin America". The Brazilian government policy has given priority to the process of internationalization of universities by creating new institutions with integrative concepts. Examples of the more well known processes are both the Federal University for Latin American Integration (Unila) founded in 2007 in Foz do Iguaçu, and the University for International Integration of the AfroBrazilian Lusophony (Unilab), which opened in 2010 in the State of Ceará. Still, at Foz do Iguaçu, the Faculty Union of the Americas (Uniamerica) running since 2001, has also a different and unifying process of communities and organizations.

It is worth remembering that in Brazil, the South-North international cooperation focus has always continued to occur by encouraging students, teachers and researchers to carry out programs and internships outside Brazil. Both the Coordination for the Improvement of Higher Education Personnel (CAPES) and the National Council for Scientific and Technological Development (CNPq) founded in 1951, have played important roles in fostering education and the research in Brazil and abroad. A very recent experience fostering international mobility of Brazilians is the program Ciência sem Fronteiras (Science without Borders) released in 2011, targeting to undergraduate and graduate students, supported by CAPES, CNPq and the Departments of Higher Education and Technological Education of the Brazilian Ministry of Education and Culture (MEC). This program also encourages well-known international researches to spend time working in Brazil.

In general, the Brazilian higher education system has always been international, but since 1998 its internationalization received support from the United Nations Educational, Scientific and Cultural Organization (UNESCO) leading to an expansion by internal changes in pedagogical institutions, new rules of the market and influx of international students (Zamberlam; Corso et al., 2009). Morosini (2006) also identifies internationalization as a process that affects all the university spheres and explains that universities have always had international research, but only since the 1990 worldwide, and in Brazil alike, universities became more international in the educational sphere. Furthermore, Marrara (2007) evaluating the Brazilian graduate programs distinguishes two different forms of internationalization, 
one active and another passive. While the active form relates to processes that lead an institution to become a center, the passive form does not.

It is possible that the process of internationalization at both the Brazilian university system and research institutions will have similar effects to those already studied in other countries. One is to continue promoting exchanges of qualified people. In fact, foreign students' mobility persists in the First World societies, which receive many foreigners and have more established courses at the graduate level (Velho, 2001). Another likely outcome is the attempt by policy makers to quantify the costs and benefits of international exchanges. However, the educational result in students' mobility is not easy to evaluate since it may depend on diverse political, economical, social and cultural contexts and people.

\section{Challenges of the internationalization for educational and research institutions}

With the growing internationalization of universities and research institutes around the globe, new challenges emerge for promoting intercultural and inclusive educational. In fact, the challenges of international student mobility are both institutional and individual. On the institutional level, the curriculum needs adjustments. Moreira and Macedo (1999) emphasize the need for institutions to adopt a cosmopolitan perspective in the curriculum, to lead to the engagement at the individual level to open relationships with the culturally diverse other. This requires eliminating prejudices and a great selfreflection of all subjects involved to promote respect for diversity, whether nationals or foreigners. While they are countless examples of prejudices in educational practice, some are particularly impressive. For instance, Silva and Morais (2012) explain that students from different nations speaking Portuguese complain the lack of tolerance by professors in two Brazilian universities. Therefore, intercultural education does demand respect of people's differences (Sousa, 2004). This is by no means an easy task because all living in hierarchical societies, professors and students alike, have learned to value people in different ways according to their ethnicity, social class, gender, age, religion and nationality.

In terms of contents, the adequacy of the curriculum to the countries' of origin of foreign students has always been questioned. Study Abroad Programs may not have coordinated policies towards the needs of these students' countries of origin. Therefore, Vizentini (2005) discussing the process of internationalization of the universities, stresses the need for reciprocity in academic cooperation to prevent colonization of the exchange. Therefore, there is the need of updating contents and practices according to the diverse needs of students and to the relevance to each social context that students aim to work with.

Because the curriculum is a space for cultural exchanges, Macedo (2006), while discussing the curricula, conceives it as a mix of cultures and negotiation of differences. Therefore, international cooperation must take place on an egalitarian basis for either party considering the contributions that programs can give to their students and vice versa. This is of paramount importance since foreign students either can return to their home countries or can become future migrants contributing to other countries.

A cosmopolitan perspective is a demanded skill for students in a globalized economy. Mol (2011) cites several studies concluding that studying abroad can influence future migration and aspiration for different jobs. Further, Robertson (2008) conducted a thorough research investigating students who become migrants in Australia and emphasized that for some seeking to become beforehand a foreign student is a rational strategy for migration. Moreover, Desidério (2006) discusses the future projects of African students in Rio de Janeiro who signed to return to their home countries after finishing their studies. While only a small number of these students considered that this obligation is not necessary to follow, some of them explained that staying in Brazil after studies' completion could depend on job prospects' opportunities allied with the legal status of being able to stay in the country.

Another important dimension of globalization it that it has been increasingly emphasized the economic and cultural contribution of the presence of foreign students in a host country. Lima and Maranhão (2009: 587) point out:

More than ever, attracting international students come to represent currencies resulting from the imposition of registration fees, tuitions and associated costs (through fellowships or investments from their families) students must pay for (transportation, housing, food, health, leisure, etc.) during their stay: without disregarding the potential to promote the host country (language, culture, political and economic interests etc.) in the country of origin at the end of education.

Nevertheless, there are challenges faced by members of the host and origin societies alike in terms of contents. An intercultural curriculum to value diversity must take into account the needs of all people living in any nation, regardless of any social marker. In the particular case of health, this is difficult to do in Brazil since the curricula in health have been very marked by an emphasis on technology, expertise, rules and high costs and less focus has 
been given to the primary care health of populations considering ethical issues (Albuquerque; Batista et al., 2009). Therefore, the health curricula should encompass debates of the way cultural, economic, ethical and political conflicts affect this field and hamper the promotion of public health in different regions and countries. Educating in health curricula should exist to try to create a more equal and sustainable world.

The fact that foreign students come from various nations with very different linguistic, cultural and social experiences becomes a challenge in terms of meaningful interactions for all concerned. Although all social actors may face many challenges, the foreign student body is likely to be the most vulnerable. While foreign students seek, through an undergraduate or graduate program, a special experience and a different place in the world, the pursuit of a program abroad in another context demands a series of personal skills such as curiosity, courage and patience. Although the experiences of students in any program are beyond or below their initial expectations, the entrance in an educational program is not always a well-planned process and depends upon economical opportunities.

Despite all the odds, Mazza (2011) in her research with international students at the University of Campinas reveals that the dream of studying abroad makes them to endure the related difficulties about discrimination and unequal processes. Garcia and Goes (2010), in a study of foreign students from Guinea-Bissau and São Tomé and Príncipe at the Federal University of Espírito Santo, emphasize the difficulty of making friendships with Brazilians and proposes the development of programs to integrate these students culturally, socially and scientifically. Nogueira (2013), in turn, in a study of international students in Paraíba, found that they tended to report not feeling much difficulty in adapting to Brazil, but the author discusses how ambiguous can be the experience of hospitality.

Foreign students undeniably depend on the symbolic and material support received before and during their stay in Brazil. The evaluation of their support system depends on how the student remains in the country, alone or accompanied, if backed by an institution, and whether or not keeping up frequent contacts with relatives and if they make new friends. Thus, the nature and duration of such support, in turn, influence the sociocultural integration and performance in the academic work of students. In reality, different social actors from academic, religious and consular institutions are likely to play a significant role in integrating students. Gusmão (2011), studying African students in Brazil, shows the following agencies supporting students: the Brazilian Undergraduate Student Program Agreement (PEC-G), the governments of the home countries and the families.

Students' expectations influence their choice to study in the Brazilian context. There is always a hierarchy of importance of educational programs and students consider conquering their goals by examining if the option is affordable, enjoyable, challenging, prestigious, and so on. Yet, students' highest aspirations for educational programs might not be linked directly to the ones they end up enrolling. Andrade and Teixeira (2009), conducting a survey in southern Brazil, show how almost half of the students did not choose their first choice of studies and gave priority to the opportunity to earn a college degree. Still, due to being a foreigner, a student may have greater difficulty in choosing the most proper program in another nation. Moreover, although the new technologies make possible to have more information about programs through their institutional sites, not all information is available about the institutional culture.

\section{The Brazilian role in fostering professionals' and students' mobility in the health field}

Brazil has played a leading role in the training of health professionals from other countries with the cooperation called South-South, especially with countries of South America and Africa (PiresAlves; Paiva et al., 2012). Almeida; Campos, et al. (2010) analyze in detail how this cooperation has stressed the need for building a kind of sustainable development encompassing education of human resources, organizational empowerment and institutional development. It is important to emphasize that while Brazil is prominent compared to other countries in some aspects of health education; there is also a shortage of health professionals in some regions, which has been widely publicized in the media. The lack of health professionals, such as physicians, spurred the formation of the Programa mais Médicos (More Physicians Program), which brought 2,400 Cuban physicians to Brazil in 2013 (La Información, 2013). This program originated trying to cope with the shortage of Brazilian physicians, welcoming and empowering foreign physicians to work in Brazil and to improve comprehensive health care in the country, especially in the most needed areas (Programa mais Médicos, 2015).

Brazilian governmental actions in promoting Brazilian professionals' and students' mobility in many fields, including the health field, are many. Examples are programs fostered by Coordination for the Improvement of Higher Education Personnel (CAPES), which has invested both in leading Brazilians to have experiences outside Brazil as well as bringing foreign students from other countries to gain experience in Brazil. For instance, CAPES formed in October of 2013, a new Mobility Program to Medical Students in the United States with the Case Western Reserve University (CWRU). In addition, there is a program for Students of Mozambique and Angola, which includes the area of health, among others. 
This is an initiative promoted by CAPES, since 2007, and the Ministry of Foreign Affairs with university research institutions in Brazil.

The program Ciência sem Fronteiras (Science without Borders), created in 2011, also encompasses the field of health. This program is an initiative intended primarily for Brazilian undergraduate students $(78 \%)$ to study abroad, but also with opportunities of fellowships for graduate Brazilian students and researchers to carry out internships abroad. A few internationally renowned researchers also obtain grants to spend time in Brazil. This program has the support of the Ministries of Science, Technology and Innovation (MCTI) and the Brazilian Ministry of Education (MEC), through their respective funding agencies - (CNPq) and (Capes) - and the higher education and technology departments associated with the Brazilian Ministry of Education (MEC). This program privileges the areas of Engineering, Biology, Biomedicine and Health Sciences. According to a preliminary evaluation report, Brazilian students have received fellowships to study in the North countries, such as the United States, United Kingdom, Canada, France and Australia. (Ciência sem Fronteiras, 2015).

Even though it is clear that there are demands for health professionals in many nations such as the nurses and physicians in Portugal (Baganha; Ribeiro, 2007) and nurses in Latin America (Marziale, 2009), and that academic institutions should address the mobility of students and professionals in the health fields. Yet, how academic institutions tackle the process of internationalization needs more research. Therefore, this paper describes how the initiative of welcoming seminars in one institution dedicated to health can be relevant to the social actors involved.

\section{The welcoming seminars by Oswald Cruz Foundation}

The research method is qualitative (Chizotti, 1991), which is adequate to understand the experiences of the institutions and the individuals. The results presented here focus on both welcome seminars held at the main campus of the institution in Rio de Janeiro in 2014 and 2015 and two interviews conducted with women, working as administrators. One of this administrator works for the Centre for International Relations in Health (CRIS) of the institution and the other is responsible for graduate students. It is important to highlight that the focus of this paper is to describe the welcome seminars because they end up progressively integrating more international students with Brazilian students and professionals. Furthermore, this is a participatory research because the author works as a researcher and professor in this institution and teaches classes to some of the Brazilian students present in the second seminar. Content analysis was the method chosen for understanding the internationalization experience, through interpreting the voices of administrators and students. This is an approach that emphasizes communication as an useful tool for investigating a reality beyond the message itself (Bardin, 1977).

Oswald Cruz Foundation (Fiocruz) has completed 115 years, playing a prominent role in public health research in Brazil. The oldest campus of the Oswaldo Cruz Foundation (Fiocruz) is in Rio de Janeiro. This institution is located in ten states in Brazil and has an office in Maputo, Mozambique. The institution has a high degree of internationalization, holding agreements with several nations. For instance, as of September 15th 2015, Oswaldo Cruz Foundation webpage makes references to a total eighty-three agreements for cooperation with: Argentina, Benin, Cape Verde, Canada, Chile, China, Colombia, France, Guinea-Bissau, Germany, Mozambique, Nigeria, Panama, Peru, Portugal, Spain, United Kingdom, United States of America, Tanzania and Venezuela (Fundação Oswaldo Cruz, 2015). However, despite this great diversity of countries enumerated, the institution clearly develops more cooperation with institutions based in Europe and the Americas.

Oswald Cruz Foundation is primarily dedicated to research. In the area of education, it has a High School, as well as technical and graduate programs. However, it does not have undergraduate programs. The institution enrolls many graduate and technical programs in the areas of Biology, Medicine, Public Health, Human and Social Sciences. These two levels of programs attract students from other institutions in Brazil and from other countries. Both the technical and graduate programs offered by the institution are broadly defined in the areas of Biology, Medicine, Public Health, Humanities and Social Sciences. The institution has in Brazil a total of eleven international researchers and ninety international students enrolled at master and doctoral programs at the institution. These figures do not encompass all the international students' enrollment in programs offered by the institution because some of its courses happen outside Brazil. For instance, its oldest institutional unit offers international courses in partnership with institutions from Argentina and from Mozambique.

It is important to note that the students' guide published by the institution dedicates a section to international students. In this section, besides giving information about Oswald Cruz Foundations' Centre for International Relations in Health (CRIS), it also gives instructions on how to get registration with the Brazilian Federal Revenue, a temporary visa for foreigners and a banking account. The Centre for International Relations in Health (CRIS) publishes a newsletter since September 2012, and its number eighteen included an article about students' mobility (Crisinforma, 2015). 
During 2014 and 2015, at the Rio de Janeiro's campus, the author contacted and interviewed two administrators, one working for Centre for International Relations in Health (CRIS) of the institution, and the other in charge of graduate students and who, after the interview, became a key informant for taking a very active role in the welcome seminar of 2015 . The content analysis evinced that the administrators' views of the problems faced by international students matched more students' concerns in the welcome seminar of 2015 than in the welcome seminar of 2014 . For instance, in the first seminar the organizers discussed as if all students were temporarily in the country and a few of the people present were former foreign students and revealed that they were for a long time present in Brazil with no project to return to their home county as long as they find jobs. This change in the focus of the course in the following year may relate to the fact that more knowledge about international students' concerns and realities were taking into consideration. Indeed, in the second seminar became obvious the administrators attempted to help international students to acquire documentation.

Observations evinced a trend towards integrating international students with national students. The first seminar lasted eight hours and a half hours and the second took five hours. The first welcome seminar of 2014 was only designed to have international students. Other people, such as the author, asked to participate on the day of the event.

The latter welcome seminar, in 2015, targeted both foreign students and students from other states of Brazil, and provided opportunity for all Brazilian students and professionals to take part and to discuss possible improvements in their conditions as students and professionals. During the seminar of 2015, the introduction included presentation of the origin of all students registered for it, revealing international students' nationalities and the states of origin of all Brazilian students. Most registered students were Brazilians and most of them came from the Southeast, followed by the Northeast, the South, the Midwest and the North. The international students registered were from the following eleven countries: Chile, Colombia, Cuba, Ethiopia, France, Haiti, Mexico, Mozambique, Paraguay, Portugal and the United States. Most students registered were female studying towards their Master degrees.

In this second welcome seminar, it was also revealed the greater difficulties experienced by international student population, according to a survey. The students claimed to need help in affordable housing, documentation to stay in the country, opening a banking account, cultural adaptation, learning the Portuguese language spoken in Brazil, transportation to the institution and better knowledge of the research institution. During the 2015 welcome seminar, an administrative staff of the institution presented solutions for shared and collective transportation and reasonable price restaurants. The open discussion provided acknowledgment of the difficulties that do not relate to all students. These related to the conditions of a few families that had made adjustments to allow one of its members to be away or to come together with the students, like a family reunion. Moreover, some workers who were present also discussed creating sidewalks to walk in some parts of the Fiocruz campus and other public transportation options, concerns not raised by students but, nevertheless, agreed by them. At the end of this seminar, some students voiced their concern for the need of a wellbeing policy in the institution. The workers present in the seminar embraced this policy.

\section{Conclusion}

This study concentrated on two interviews and observations in the first two initiatives of welcoming seminars. Therefore, it can by no means be extensive of what occurs in the institution. Yet, in these welcome seminars, discussion of the difficulties of being a student, either foreign or Brazilian were given attention. While some problems are not of easy solution, work has been done to tackle some needed changes. The inclusion of both types of Brazilian students, those living in other states and those from Rio de Janeiro in the 2015 edition of the welcome seminar seems a relevant development when compared to its first edition in 2014.

The more inclusive a seminar is in terms of who can take part has more chances of fostering social integration. Because students may experience similar problems, regardless of nationality, sharing them was important to promote group cohesion. For example, sharing the same problems issues of public transportation, affordable housing and restaurants was relevant. So in the end, the institution targeted all students to propose solutions and the move towards integrating international students with the Brazilian's ones seemed worthy.

These events teach that working with practical issues such as documentation, access to public transportation and more affordable housing concerns the whole student body, both internationals and nationals. Thus, working with students' practical issues seemed to have provided them a feeling of being cared and listened by the institution. Therefore, this institution should continue to sponsor and amog debates with and among together. This collective task does not mean, however, to neglect the specific academic and professional demands of each student and the periods of adjustments that each one needs, whether they are foreign or not. Moreover, the opportunities to meet others may 
indicate that the social actors studying and working in the institution will need to continuously recreate themselves by reviewing their own prejudices to carry out respectful relationships with cultural diverse people from Brazil and other nations.

\section{References}

ALBUQUERQUE, V. S.; R. S. Batista, et al. (2009), "Currículos disciplinares na área de saúde: ensaios sobre saber e poder", Interface-Comunicação Saúde Educação, 13 (31), pp. 261-272.

ALMEIDA, C.; R. P. Campos, et al. (2010), "A concepção brasileira de cooperação Sul-Sul estruturante em saúde", RECIIS - R. Eletr. de Com. Inf. Inov. Saúde. Rio de Janeiro, 4 (1), pp. 25-35.

ANDRADE, A. M. J. de e M. A. P. Teixeira (2009), "Adaptação à universidade de estudantes internacionais em um estudo com alunos de um programa de convênio", Revista Brasileira de Orientação Profissional, 10 (1), pp. 33-44.

BAGANHA, M. I. e J. S. Ribeiro (2007), "Imigração qualificada no sector da saúde-as oportunidades do mercado laboral português", Revista Migrações, 1 , pp. 53-78.

BARDIN, L. (1977), Análise de conteúdo, São Paulo, Edições 70.

CASTRO, A. A. e A. Cabral Neto (2012), "O ensino superior: a mobilidade estudantil como estratégia de internacionalização na América Latina", Revista Lusófona de Educação, 21, pp. 69-96.

CHIZzOTTI, A. (1991), Pesquisas em Ciências Humanas e Sociais, São Paulo, Cortez.

CIÊNCIA SEM FRONTEIRAS (2015). Available at: http://www.cienciasemfronteiras.gov.br/web/ csf/views/-/journal_content/56_INSTANCE_ VF2v/214072/5100172. Date of access: 15 th July of 2015.

CRISINFORMA (2015), Informativo do Centro de Relações Internacionais de Saúde da Fiocruz, 18, jan-fev. Available at: http://www.agencia. fiocruz.br/sites/www.agencia.fiocruz.br/files/ crisInforma/Cris_Informa_18.pdf. Date of access: May 10th 2015.

DESIDÉRIO, E. J. (2006), "Migração internacional com fins de estudos: o caso dos africanos do programa estudante-convênio de graduação em três universidades públicas no Rio de Janeiro", Dissertação de mestrado do Programa de Pós-Graduação em Estudos Populacionais e Pesquisas Sociais da Escola Nacional de Ciências Estatísticas - ENCE, Rio de Janeiro.

FUNDAÇÃO OSWALDO CRUZ (2015), Relatório de convênios internacionais vigentes, Centro de relações internacionais em saúde/ Cris. Atualizado em 15/09/2015. Available at: http://portal.fiocruz.br. Date of access: September 29th 2015.

GARCIA, A. e D. C. Goes. (2010), "Amizade de estudantes africanos residindo no Brasil", Psicologia: Teoria e Prática, 12 (1), pp. 138-153.
GUSMÃO, N. M. M. (2011), "Na terra do Outro: presença e invisibilidade de estudantes africanos no Brasil, hoje", Dimensões, 26, pp. 191-204.

KING, R. e P. Raghuram (2013), "International student migration: mapping the field and new research agenda", Population, space and place, 19, pp. 127-137.

KRAWCZYK, N. R. (2008), "As políticas de internacionalização das universidades no Brasil: o caso da regionalização no MERCOSUL", Jornal de Políticas Educacionais, 4, pp. 41-52.

LA INFORMACIÓN (2013), BRASIL RECIBE TRES MIL MÉDICOS CUBANOS PARA ATENDER ÁREAS REMOTAS. Available at: http://noticias.lainformacion. com/asuntos-sociales/inmigrantes-ilegales/brasilrecibe-tres-mil-medicos-cubanos-para-atenderareas-remotas_4YmkJETArRVHofqHL27kw6/. Date of access: November $7^{\text {th }}$ November 2013.

LIMA, M. C. e C. M. S. de A. Maranhão (2009), "O sistema de educação superior mundial: entre a internacionalização ativa e passiva", Avaliação, 14 (3), pp. 583-610.

MACEDO, E. (2006), "Currículo: política, cultura e poder", Currículo sem fronteiras, 6 (2), pp. 98-113.

MARRARA, T. (2007), "Internacionalização da Pós-Graduação: objetivos, formas e avaliação", $R e$ vista Brasileira de Pós-Graduação RBPG, 4 (8), pp. 245-262.

MARZIALE, M. H. P. A. (2009), "A transnacionalização regional da Enfermagem da América Latina", Rev. Latino-Am. Enfermagem, 17 (1), pp. 3-4.

MAZZA, D. (2011), "Mobilidade humana e educação: os estudantes estrangeiros na UNICAMP", Cadernos CERU 2, 22(2), pp. 239-255.

MOL, C.V. (2011), "The influence of student mobility of future migration aspirations. Empirical evidence from Europe and recommendations to study the impact of international exchange programmes", Canadian Diversity, 8 (5), pp. 105-108.

MOREIRA, A. F. e E. F. Macedo (1999), "Fazendo sentido ainda o conceito de transferência educacional?", in A. F. Moreira (org.), Currículo: políticas e práticas, Campinas, SP, Papirus, pp. 11-28.

MOROSINI, M. C. (2006), "Estado do conhecimento sobre internacionalização da educação superior-conceitos e práticas", Educar, 28, pp. 107-124.

MOROSINI, M. C. (2011), "Internacionalização na produção de conhecimento em IES Brasileiras: cooperação internacional tradicional e cooperação internacional horizontal", Educar em Revista, 27, pp. 93-112.

NOGUEIRA, S. G. (2013), "Entre o burocrático-legal e a hospitalidade: os estudantes internacionais na Paraíba e a Polícia Federal", Interseções, 15 (1), pp. 29-47.

OJIMA, Ricardo; M. A. C. Aguirre; et al. (2014), "Migrações internacionais motivadas por estudo: uma análise sociodemográfica dos estudantes estrangeiros radicados no Brasil". Revista PerCursos, 15 (28), pp. 166-189. 
PIRES-ALVES, F. A.; C. H. A. Paiva, et al. (2012), "A internacionalização da saúde no Brasil: elementos contextuais e marcos institucionais da cooperação internacional brasileira em parceria com a OPAS", Rev. Panam Salud Publica, 32 (6), pp. 444-450.

PROGRAMA MAIS MÉDICOS (2015), Available at: http:// maismedicos.gov.br/. Date of access: September $23^{\text {rd }}$ of 2015.

ROBERTSON, S. K. (2008), "Negotiated Transnationality: Memberships, Mobilities and the StudentTurned-Migrant Experience", PhD Thesis, School of Global Studies, Social Science and Planning, RMIT University.

SILVA, K. e S.S. Morais (2012), "Tendências e tensões de sociabilidade de estudantes dos Palop em duas universidades brasileiras", Pró-Posições, 23 (1), pp. 163-182.
SOUSA, I. C. F. de (2004), "A educação intercultural na escola e o reconhecimento do Outro diferente", Archivos Analíticos de Políticas Educativas / Education Policy Analysis Archives, 12 (59), pp. 1-8.

VELHO, L. (2001), "Formação de doutores no país e no exterior: estratégias alternativas ou complementares", Dados. Revistas de Ciências Sociais, 44 (3), pp. 607-631.

VIZENTINI, P. F. (2005), "A transição do sistema mundial e a internacionalização das universidades: uma perspectiva brasileira", Porto Alegre. Available at: http://www.andifes.org.br/index. php?option $=$ docman\&task $=$ doc. Date of access: August $1^{\text {st }} 2008$.

ZAMBERLAM, J.; G. Corso, et al. (2009), "Estudantes internacionais no processo globalizador e na internacionalização do ensino superior", Porto Alegre, Impa Artes Gráficas e Ltda.

Recebido a 01/10/2015. Aceite para publicação a 04/12/2015.

Isabela Cabral Félix de Sousa (isabelacabralfelix@gmail.com). Fundação Oswaldo Cruz, Escola Politécnica de Saúde Joaquim Venâncio, Laboratório de Iniciação Científica na Educação Básica. Avenida Brasil 4365, 21045-900 Manguinhos, Rio de Janeiro, Rio de Janeiro, Brasil. 